\title{
IMPROVING THE CORROSION RESISTANCE OF THE AZ61 MAGNESIUM ALLOY WITH A HOMOGENIZATION TREATMENT BEFORE THE EXTRUSION-SHEAR PROCESS
}

\author{
IZBOLJŠANJE KOROZIJSKE ODPORNOSTI MAGNEZIJEVE \\ ZLITINE AZ61 S HOMOGENIZACIJO PRED POSTOPKOM \\ STRIŽNEGA IZTISKOVANJA
}

\author{
Zhi Yan ${ }^{1}$, Hong Xing ${ }^{1}$, Hu Hongjun ${ }^{1 *}$, Zhang Dingfei ${ }^{2}$, Ou Zhongwen ${ }^{3}$, Gou Yinning ${ }^{1}$, \\ Chai Linjiang ${ }^{1}$ \\ ${ }^{1}$ Chongqing University of Technology, Chongqing Key Laboratory of Mold Technology, College of Materials Science and Engineering, \\ no. 69 Hongguang Road, Banan District, Chongqing 400050, China \\ ${ }^{2}$ Chongqing University, National Engineering Research Center for Magnesium Alloys, no. 174 Shazhengjie, Shopingba District, \\ Chongqing 400044, China \\ ${ }^{3}$ Army logistics University of PLA, Chemical and Materials Engineering, no. 20 North City Road, Shopingba District, 401311, China \\ hhj@cqut.edu.cn
}

Prejem rokopisa - received: 2018-05-16; sprejem za objavo - accepted for publication: 2018-07-20

doi:10.17222/mit.2018.102

\begin{abstract}
The corrosion resistance of the AZ61 magnesium alloy with and without a homogenization treatment fabricated using the extrusion-shear (ES) process was investigated and evaluated using electrochemical tests. The influences of $\mathrm{NaCl}$ concentrations on the corrosion behavior of the samples were studied. The corrosion morphologies of the corrosion products were analyzed by SEM and X-ray diffraction. Electrochemical measurements of the magnesium alloy in NaCl solutions with different concentrations were conducted. The research results show that homogenization treatments before the ES process can improve the corrosion resistance of the AZ61 magnesium alloy significantly. The influences of the homogenization treatments on the corrosion resistance were found to be associated with the uniformity of the grain sizes and the re-distributions of intermetallic particles within the microstructures.

Keywords: corrosion resistance, AZ61 magnesium alloy, extrusion-shear, homogenization treatment
\end{abstract}

Avtorji prispevka so raziskali in z elektrokemičnimi testi ovrednotili korozijsko odpornost homogenizirane in nehomogenizirane $\mathrm{Mg}$ zlitine AZ61. Raziskovali so vplive koncentracije NaCl na korozijsko obnašanje vzorcev. Morfologijo korozijskih produktov so analizirali z vrstičnim elektronskim mikroskopom (SEM) in rentgensko difrakcijo (XRD). Izvedli so elektrokemične meritve Mg zlitine v raztopinah $\mathrm{z}$ različno koncentracijo $\mathrm{NaCl}$. Rezultati raziskav so pokazali, da lahko homogenizacija pred strižno ekstruzijo (ES angl.: Extrusion-Shear process) znatno izboljša korozijsko obstojnost Mg zlitine AZ61. Izboljšanje je posledica povečanja homogenosti mikrostrukture (enovitosti velikosti kristalnih zrn) in redistribucije delcev intermetalnih faz znotraj le-te.

Ključne besede: odpornost proti koroziji, magnezijeva zlitina AZ61, strižna ektruzija, homogenizacijsko žarjenje.

\section{INTRODUCTION}

Magnesium (Mg) alloys are used in a variety of industries, ${ }^{1,2}$ such as communications, transportation, aerospace and electronics, due to their characteristics, especially their high strength-to-weight ratios compared to other superalloys, ${ }^{3}$ such as stainless steel, ${ }^{4,5}$ titanium alloys ${ }^{6,7}$ and nickel-based superalloys. ${ }^{8,9}$ Nowadays, the large-scale production of wrought $\mathrm{Mg}$ alloy products produced by plastic processing, such as plates, rods and tubes, are in great need as they have good comprehensive properties and can meet various application requirements. ${ }^{10-12}$ However, $\mathrm{Mg}$ alloys have a poor corrosion resistance, because secondary phases or impurity elements can cause galvanic corrosion and oxidation films on the surface of the $\mathrm{Mg}$ alloys, which have a porous structure and cannot protect the $\mathrm{Mg}$ alloys from corrosion effectively, compared to other alloys, ${ }^{13-16}$ especially in special environments, such as high chlorine-ion contents. The compositions of $\mathrm{Mg}$ alloys also have significant influences on the microstructures, which also affect the corrosion resistance.

The corrosion properties of $\mathrm{Mg}$ alloys could be improved by purifying the alloy compositions, developing new alloys by adding rare-earth elements, ${ }^{17-19}$ surface treatments that could cover the surface of the metal using a layer of protective film, ${ }^{20-23}$ or optimizing the processing methods. ${ }^{24}$ One example is the severe plastic deformation (SPD) techniques, such as equal channel angular pressing (ECAP). They have attracted growing interest from specialists in materials science. ${ }^{25,26}$ Figueiredo et al. ${ }^{27}$ utilized a new processing procedure to extrude a cast $\mathrm{Mg}-9 \% \mathrm{Al}$ alloy, which involves the sequential applications of extrusion (EX) and equal channel angular pressing (ECAP). They found that the grain size of the $\mathrm{Mg}-9 \% \mathrm{Al}$ alloy reduced from an initial $50 \mu \mathrm{m}$ (casting) to $0.7 \mu \mathrm{m}$ after one extrusion process 


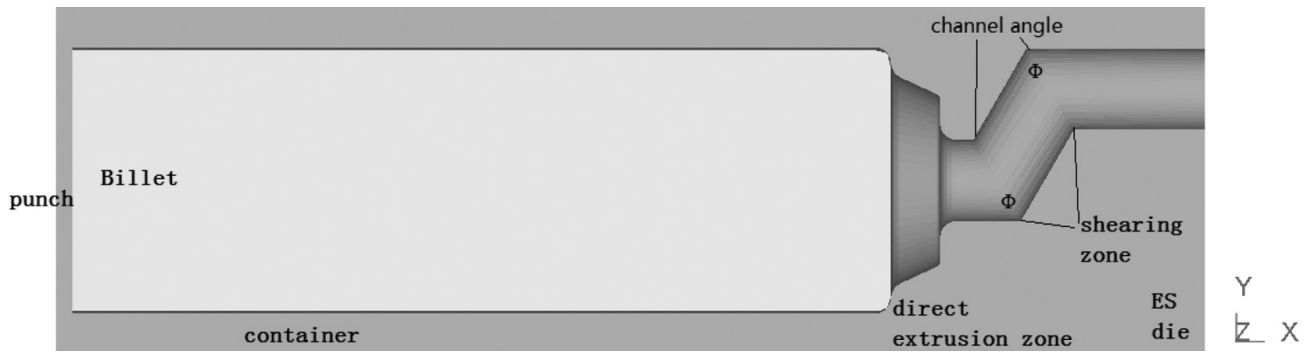

Figure 1: Schematic diagram of the ES die

and two ECAP processes. However, as EX-ECAP usually includes more than 2 steps, the materials have to endure an intricate diversification of the forming environments, which can lead to oxidization of the material due to the process temperature. Matsubara et al. ${ }^{28}$ demonstrated the feasibility of combining conventional EX and ECAP into a single process. The extruded material exhibited an excellent balance of strength and tensile ductility. But SPD technologies are difficult to promote and industrialize, the processes are very complicated, and the costs are high.

A new SPD method named the extrusion-shear (ES) process has been developed to fabricate fine-grained $\mathrm{Mg}$ alloys. ${ }^{29-31}$ The composite extrusion for the $\mathrm{Mg}$ alloy combines direct extrusion and two steps of ECAP. The ES process not only makes continuous forming possible, but also allows the various kinds of rods to be produced with the desired final dimensions. Even though numerous studies have focused on the corrosion properties of the $\mathrm{Mg}$ alloy, none of them considered factors including manufacturing routes and heat treatments. In this study, an ES die with a horizontal extruder was designed and manufactured to investigate the effects of the homogenization treatment before the ES process on the corrosion properties of the final AZ61 Mg alloy products by immersion and electrochemical performance tests. The microstructures of the samples from the as-received and ES-formed rods were observed and analyzed to determine the deformation mechanisms of the ES process, respectively.

\section{EXPERIMENTAL PART}

\subsection{Sample preparation}

Based on X-Ray fluorescence spectroscopy, the as-cast AZ61 Mg alloy samples had compositions of $6.11 w / \%$ Al, $0.87 w / \%$ Zn, $0.25 w / \%$ Mn, $0.018 w / \%$ Si with a balance of $\mathrm{Mg}$. The homogenization heat treatment was performed at a temperature of $400{ }^{\circ} \mathrm{C}$ with a holding time of $24 \mathrm{~h}$ for half of the samples. Figure 1 shows a schematic diagram of the ES process, which includes direct extrusion and two steps of ECAP. The punch can move horizontally left and right in the X-axial direction. The oblique angle $\phi$ between the two channels is called the die channel angle, which is $120^{\circ}$ in this study. The preheated temperatures for the billets and the
ES die are $400{ }^{\circ} \mathrm{C}$ and $380{ }^{\circ} \mathrm{C}$, respectively. The ES processes for the as-cast and as-homogenizrd billets were executed with an extrusion ratio of 12 at an extrusion speed of $10 \mathrm{~mm} / \mathrm{s}$.

All the specimens used in this study had a size of $20 \mathrm{~mm} \times 15 \mathrm{~mm} \times 5 \mathrm{~mm}$. They were cut from the longitudinal sections of the center ES-processed rods by line cutting to avoid the possible effects of location difference. Standard metallographic procedures were adopted to prepare the samples, which includes mounting, grinding, and polishing with a diamond suspension down to $0.5 \mu \mathrm{m}$. For the microstructures characterization, they were etched using a picric acid solution, composed of $5.5 \mathrm{~g}$ picric acid, $100 \mathrm{~mL}$ alcohol, $5 \mathrm{~mL}$ acetic acid, and $10 \mathrm{~mL}$ distilled water. The microstructures were revealed by SEM. In addition, an AD5000X X-ray diffractometer was used to identify the phase compositions of the specimens.

\subsection{Corrosion tests}

The tafel polarization curves and AC impedance in $\mathrm{NaCl}$ solutions with concentrations of $1 \%, 3.5 \%, 5 \%$, $7 \%$ and $10 \%$, respectively, at room temperature were obtained with an electrochemical work station and the corresponding analysis software, in which the specimens were used as the working electrode, and $\mathrm{Hg} / \mathrm{Hg}_{2} \mathrm{Cl}_{2}$ saturated potassium chloride was used as the reference electrode.

\section{RESULTS AND DISCUSSION}

\subsection{Microstructures of Mg alloy fabricated using the ES process}

X-ray diffraction patterns of the ES-processed samples with the as-cast and the homogenized initial state are shown in Figure 2. According to the difference in the diffraction-peak intensities, the deformation microstructures of the $\mathrm{Mg}$ alloy include a main phase, $\mathrm{a}-\mathrm{Mg}$, and a small amount of secondary phases, such as $\mathrm{Mg}_{17} \mathrm{Al}_{12}$. With the homogenizing treatment, the percentages of the composition phases were changed.

Figure $\mathbf{3 a}$ and $\mathbf{3 b}$ show SEM images for the ES-extruded AZ61 Mg alloy sample in the as-cast and homogenized initial state, respectively. Most of the massive second phases $\left(\mathrm{Mg}_{17} \mathrm{Al}_{12}\right)$ with white polygonal 


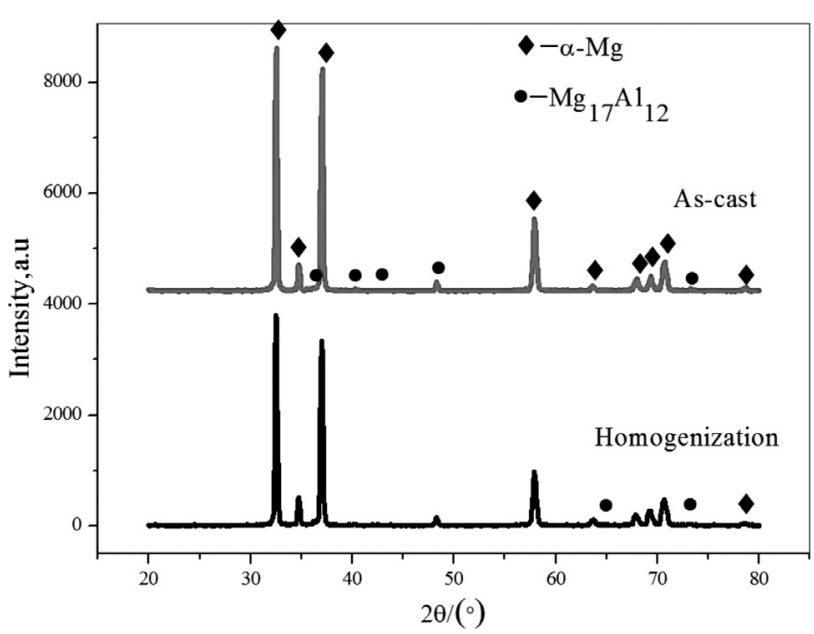

Figure 2: X-ray diffraction patterns for ES-extruded AZ61 Mg alloy with as-cast and homogenized states

shapes are distributed among the grain boundaries in Figure 3a. But in Figure 3b, the secondary phases are small and rounded, which indicates that the homogenization treatment would decrease the elements' segregation between the grain boundaries. In addition, the homogenization treatment before the ES process would
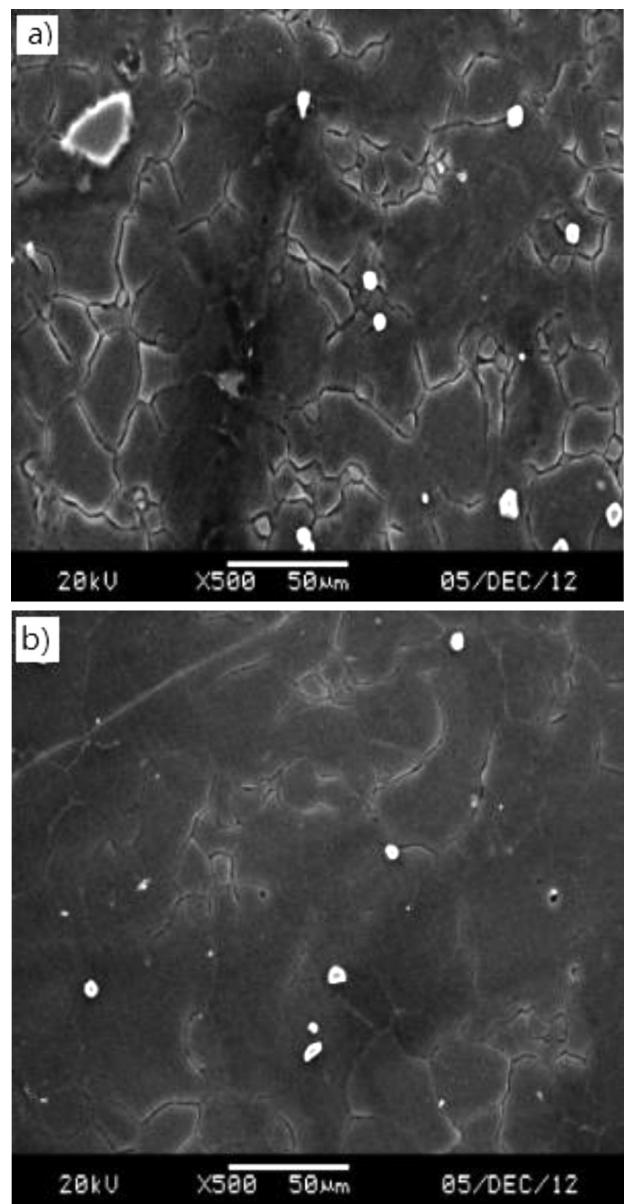

Figure 3: SEM micrographs of ES-extruded AZ61 Mg alloy samples, a) as cast, b) homogenized initial state make the distributions of the secondary phases more even.

\subsection{Electrochemical measurements}

The impedance in the $\mathrm{NaCl}$ solution with various concentrations are high-frequency capacitance arcs with some scatter in the low-frequency regions, as shown in Figure 4. The radius of the arc indicates the quality of the corrosion resistances for the $\mathrm{Mg}$ alloy matrix. Generally, the radii of the capacitance arcs decrease with the concentration of the $\mathrm{NaCl}$ solution increasing from $1 \%$ to $10 \%$. In addition, the modulus of the $\mathrm{NaCl}$ solutions reduce as the concentration of the $\mathrm{NaCl}$ solution increases from $1 \%$ to $10 \%$.

In the same corrosion periods, where the concentration of $\mathrm{NaCl}$ increases from $1 \%$ to $5 \%$, the corrosion areas increased, and the corrosion holes deepened, which indicates an increase of the corrosion degree. At a concentration of $7 \%$, the surface of the AZ61 Mg alloy was damaged severely, and the corrosion developed from
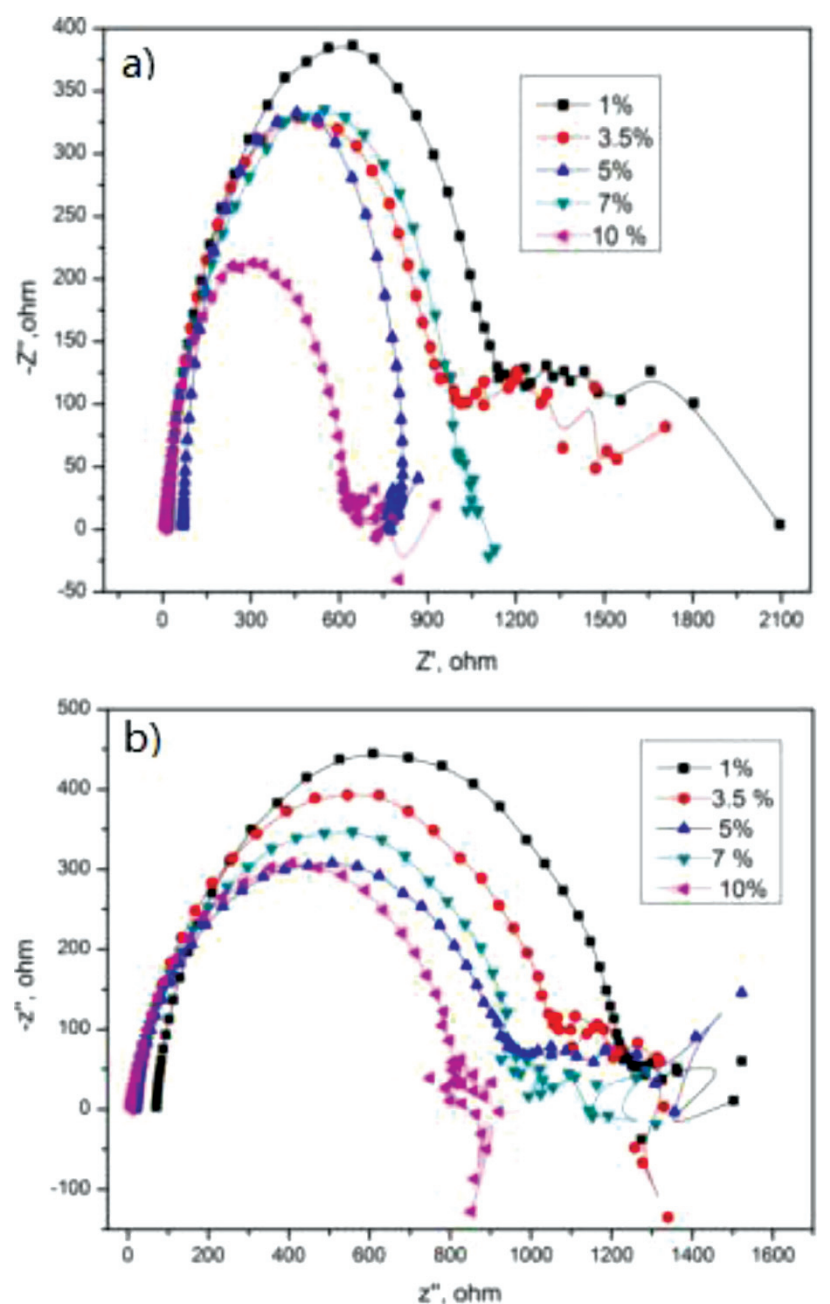

Figure 4: Impedance of AZ61 Mg alloy fabricated using the ES process in $\mathrm{NaCl}$ solutions with different concentrations, a) as cast, b) homogenization treatment 


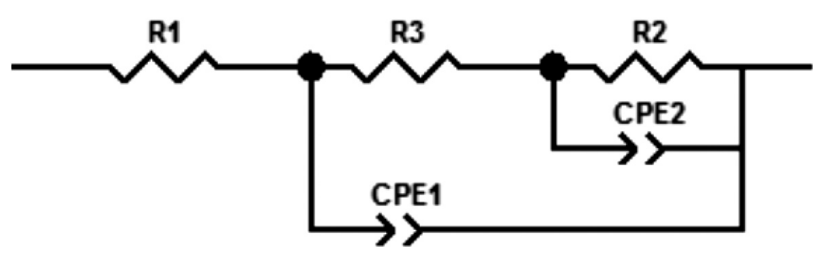

Figure 5: Equivalent circuit based on impedance spectrum fitting pitting corrosion to affect the entire surface of the sample (general corrosion), which would lead to an increase of the model values. ${ }^{32,33}$

EIS plots of the as-cast and homogenization samples show two capacitance arcs (Figure 4), which indicate that there are at least two time constants in the process of the electrode reaction. The capacitance arc at high frequency represents the influence of the charge-transfer resistance R3 and the double-layer capacitance. The appearance of the capacitance arc at low frequency explains that the barrier layer, which blocks the diffusion and transfer of ion, has formed. It represents R2 and the film capacitance when the ion diffuses in the corrosion product film. Figure 5 is the equivalent circuits (EC) of EIS. R1 and R2 represent the solution resistance and the charge-transfer resistance, respectively. R3 represents the resistance that is caused by the ion diffusing in the corrosion product film on the $\mathrm{Mg}$ alloy surface. CPE is the constant-phase element. Table $\mathbf{1}$ and $\mathbf{2}$ show the EIS fitting results in different conditions.

Table 1 shows the fitting results of the as-cast AZ61 in different $\mathrm{NaCl}$ solution concentrations. The radius of the capacitance arc at high frequency diminishes with the increasing solution concentration, which explains that the high solution concentration accelerates the anodic active dissolution process. The value of R2 decreases from $1743 \Omega$ to $943.7 \Omega$, which can prove this method. The capacitance arc at low frequency indicates that the corrosion product $\mathrm{Mg}(\mathrm{OH}) 2$ has formed on the surface of sample, and corrosion product increases with the increasing of the corrosive media concentration. The value of R3 increases from $0.013084 \Omega$ to $312 \Omega$, which
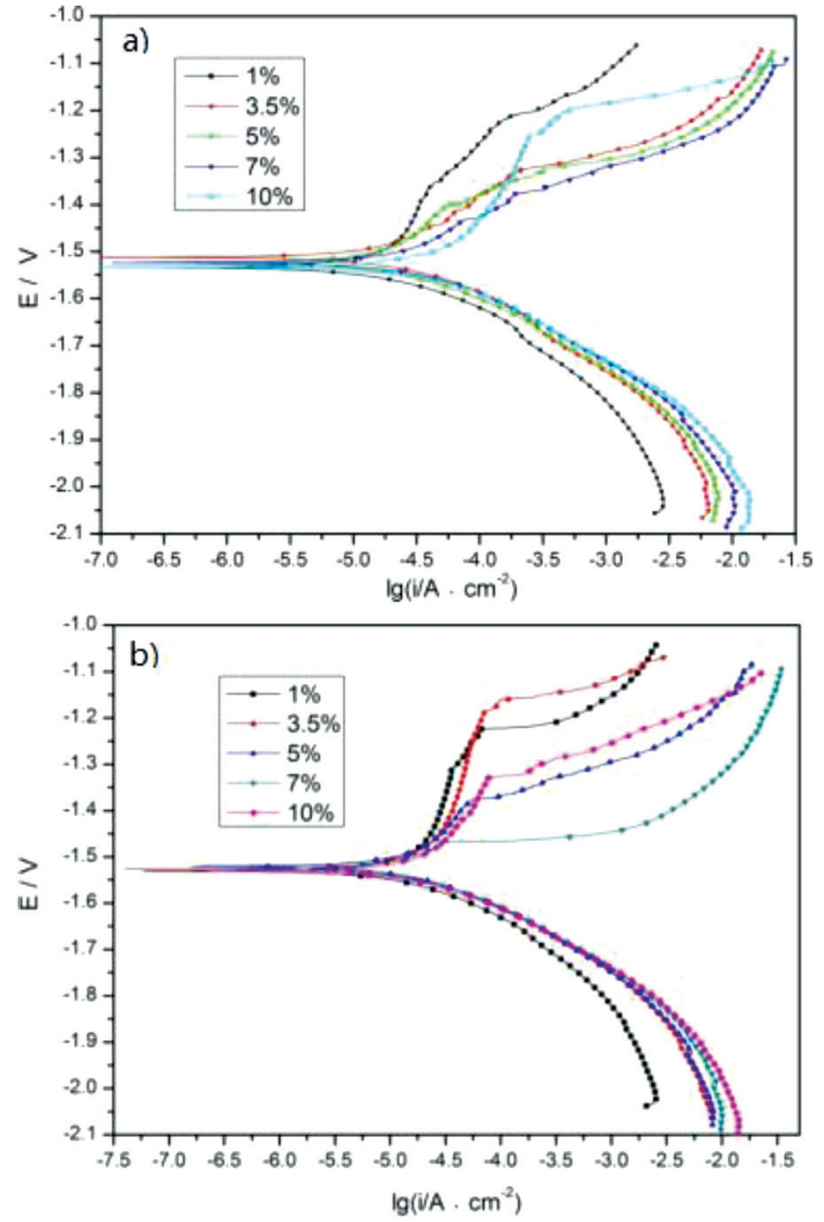

Figure 6: Potentiodynamic curves for AZ61 Mg alloy fabricated by ES process in $\mathrm{NaCl}$ solutions with different concentrations, a) homogenization treatment, b) as-cast state

can prove this method. The inductance arc appears at low frequency when the concentration of the corrosive media increases to $10 \%$, which indicates that the pitting induction period is appearing, the $\mathrm{Cl}^{-}$starts to cause the pitting on the $\mathrm{Mg}(\mathrm{OH})_{2}$ deposition film, and R3 decreases from

Table 1: Parameters obtained by the fitting of the impedance spectra demonstrated in Figure 4a

\begin{tabular}{|c|c|c|c|c|c|c|c|}
\hline $\mathrm{NaCl} \%$ & $\begin{array}{c}\mathrm{R} 1 \\
\left(\Omega \cdot \mathrm{cm}^{2}\right)\end{array}$ & $\begin{array}{c}\mathrm{R} 2 \\
\left(\Omega \cdot \mathrm{cm}^{2}\right)\end{array}$ & $\begin{array}{c}\mathrm{R} 3 \\
\left(\Omega \cdot \mathrm{cm}^{2}\right)\end{array}$ & $\begin{array}{c}\mathrm{CPE} 1-\mathrm{T} \\
\left(\Omega^{-1} \cdot \mathrm{cm}^{-2} \cdot \mathrm{S}^{\mathrm{n}}\right)\end{array}$ & $\mathrm{n} 1$ & $\begin{array}{c}\text { CPE2-T } \\
\left(\Omega^{-1} \cdot \mathrm{cm}^{-2} \cdot \mathrm{S}^{\mathrm{n}}\right)\end{array}$ & $\mathrm{n} 2$ \\
\hline $1 \%$ & 70.43 & 1743 & 0.013084 & $1.2597 \mathrm{E}-5$ & 0.89189 & 0.00025157 & 0.090165 \\
\hline $3.5 \%$ & 22.87 & 288.2 & 196.3 & $1.0735 \mathrm{E}-5$ & 0.94515 & $3.4243 \mathrm{E}-5$ & 0.63592 \\
\hline $5 \%$ & 17.02 & 2365 & 251 & $1.8634 \mathrm{E}-5$ & 0.87328 & 0.00090487 & 0.10777 \\
\hline $7 \%$ & 12.04 & 2130 & 312 & $1.8164 \mathrm{E}-5$ & 0.87109 & 0.00088419 & 0.099244 \\
\hline $10 \%$ & 9.545 & 743.7 & 102.2 & $8.7511 \mathrm{E}-6$ & 0.95444 & $3.7945 \mathrm{E}-5$ & 0.63 \\
\hline
\end{tabular}

Table 2: Parameters obtained by the fitting of the impedance spectra demonstrated in Figure 4b

\begin{tabular}{|c|c|c|c|c|c|c|c|}
\hline $\mathrm{NaCl} \%$ & $\begin{array}{c}\mathrm{R} 1 \\
\left(\Omega \cdot \mathrm{cm}^{2}\right)\end{array}$ & $\begin{array}{c}\mathrm{R} 2 \\
\left(\Omega \cdot \mathrm{cm}^{2}\right)\end{array}$ & $\begin{array}{c}\mathrm{R} 3 \\
\left(\Omega \cdot \mathrm{cm}^{2}\right)\end{array}$ & $\begin{array}{c}\text { CPE1-T } \\
\left(\Omega^{-1} \cdot \mathrm{cm}^{-2} \cdot \mathrm{S}^{\mathrm{n}}\right)\end{array}$ & n1 & $\begin{array}{c}\text { CPE2-T } \\
\left(\Omega^{-1} \cdot \mathrm{cm}^{-2} \cdot \mathrm{S}^{\mathrm{n}}\right)\end{array}$ & $\mathrm{n} 2$ \\
\hline $1 \%$ & 16.64 & 2631 & 123 & $2.3468 \mathrm{E}-5$ & 0.84336 & 0.0024413 & 0.66221 \\
\hline $3.5 \%$ & 21.46 & 2231 & 213 & $1.1782 \mathrm{E}-5$ & 0.91933 & 0.00055903 & 0.11003 \\
\hline $5 \%$ & 68.17 & 1081 & 472 & $1.539 \mathrm{E}-5$ & 0.87172 & 0.0016064 & 0.56608 \\
\hline $7 \%$ & 12.53 & 850 & 1058 & $2.8031 \mathrm{E}-5$ & 0.82657 & 0.0020704 & 0.14753 \\
\hline $10 \%$ & 9.16 & 850 & 1287 & $2.1731 \mathrm{E}-5$ & 0.85408 & 0.0012385 & 0.08905 \\
\hline
\end{tabular}


$312 \Omega$ to $102.2 \Omega$. Figure $4 \mathbf{b}$ and Table 2 show that the EIS results of homogenized AZ61 have the same trend with an increasing concentration of corrosive media.

The polarization curves of the AZ61 Mg alloy samples with and without the homogenization treatment in the $\mathrm{NaCl}$ solution with different concentrations (1\%, $3.5 \%, 5 \%, 7 \%$ and $10 \%$ ) are in compliance with the tafel rule, as shown in Figure 6. With an increase of the chlorination concentration, the corrosion degrees of the samples become serious, and the anode current densities increase. However, the slope of $\mathrm{B}_{\mathrm{c}}$ tafel only exhibits small changes.

\subsection{Analysis of causes for an improvement of the cor- rosion resistance}

In the $\mathrm{NaCl}$ solution the corrosion resistance of the $\mathrm{Mg}$ alloy is lower than that of other metals, because the $\mathrm{Mg}$ alloy has lower potentials than other metals due to the existence of porous oxide films. The electrochemical corrosion mechanisms can be explained by the following chemical reaction: ${ }^{34-35}$

At the anode: $\mathrm{Mg}+\mathrm{H}_{2} \mathrm{O}{ }^{\circledR} \mathrm{Mg}^{2+}+\mathrm{OH}^{-}+1 / 2 \mathrm{H}_{2}+\mathrm{e}^{-}$ At the cathode: $\mathrm{H}_{2} \mathrm{O}+\mathrm{e}^{-}$( $\mathrm{OH}^{-}+1 / 2 \mathrm{H}_{2}$

The possible overall reaction is:

$$
\mathrm{Mg}+\mathrm{H}_{2} \mathrm{O} \circledast \mathrm{Mg}(\mathrm{OH})_{2}+\mathrm{H}_{2}
$$

Corrosion product: $\mathrm{Mg}^{2+}+2 \mathrm{OH}^{-}{ }^{\circledR} \mathrm{Mg}(\mathrm{OH})_{2}$

In addition, the potentials of the $\mathrm{Mg}$ alloy surface are inhomogeneous as a lot of micro regions on the surface have uneven potentials. An anode reaction and a cathode reaction would occur, and the reaction occurs in the region of low and high potentials, respectively. This intensifies the corrosion of the $\mathrm{Mg}$ alloy in solution.

The corrosion resistance of the AZ61 Mg alloy samples with the homogenization treatment is superior to that of the as-cast ones. The main compositions of the alloy phases are the $\mathrm{Mg}$ matrix and the $\mathrm{b}-\mathrm{Mg}_{17} \mathrm{Al}_{12}$ phase that was observed in the inter-regional grain boundaries in the form of continuation or semi-continuation, as shown in Figure 2 and 3. In the homogenization treatment, dynamic recrystallization occurred and secondary phases transformed from semi-continuous precipitation to continuous precipitation, which would lead to the decreased corrosion rates of the $\mathrm{Mg}$ alloy. The potential differences between the precipitation of the $\mathrm{b}-\mathrm{Mg}_{17} \mathrm{Al}_{12}$ phase and non-equilibrium phases of the AZ61 Mg alloy increase in the homogenization heat-treated samples, which might lead to galvanic corrosion due to the increased driving force. This results in an increase of the corrosion rate of the alloy. The distributions of the secondary phases in the homogenization-treated samples are uniform, which leads to a non-concentrated corrosion and a dispersed corrosion current. Therefore, the pitting corrosion is changed into a uniform corrosion. This results in a remarkably decreased corrosion current.

\section{CONCLUSIONS}

In this study, to investigate the effects of the homogenization treatment on the corrosion resistance of the final ES-fabricated AZ61 Mg alloy samples, half of the received as-cast billets were homogenization-treated and then processed using the ES process. Their corrosion resistances were studied and evaluated by comparing to those without heat-treated samples using immersion and electrochemical performance tests. In comparison with the ES-processed samples without homogenization treatment, the ES-processed samples with homogenization treatment have a higher corrosion resistance as they show higher corrosion potentials in different concentrations of $\mathrm{NaCl}$ solution, a smaller corrosion current, and a higher capacitance arc radius of impedance. The ES-processed AZ61 Mg alloy samples with a homogenization treatment have a better corrosion resistance than those without homogenization treatment billets prepared by the ES process. Homogenization treatment billets before the ES process could improve the corrosion resistance of the $\mathrm{Mg}$ alloy. The corrosion resistance of the AZ61 Mg alloys with the homogenization treatment fabricated by the extrusion-shear process is superior to that of the as-cast state AZ61 Mg alloy for composition homogenization.

\section{Acknowledgment}

This work was supported by Scientific and Technological Research Program of Chongqing Municipal Education Commission (KJ1600924), Chongqing Natural Science Foundation Project of cstc2018jcyjAX0249 and cstc2018jcyjAX0653 and cstc2016jcyjA0434, National Science Foundation of China (51771038 and 51571040).

\section{REFERENCES}

${ }^{1}$ S. Li, M. A. M. Bourke, I. J. Beyerlein, D. J. Alexander, B. Clausen, Finite element analysis of the plastic deformation zone and working load in equal channel angular extrusion, Mater. Sci. Eng. A., 382 (2004), 217-236, doi:10.1016/j.msea.2004.04.067

${ }^{2}$ Y. Li, Y. Liu, D. Ni, D. Zhang, G. Guo, W. Chen, Effects of die angle on microstructures and mechanical properties of AZ31 magnesium alloy processed by equal channel angular pressing, Trans. Nonferrous Met. Soc. China, 14 (2004), 53-57

${ }^{3}$ M. S. F. de Lima, S. Sankaré, Microstructure and mechanical behavior of laser additive manufactured AISI 316 stainless steel stringers, Mater. Des., 55 (2014), 526-532, doi:10.1016/j.matdes.2013.10.016

${ }^{4}$ F. Kong, W. Liu, J. Ma, E. Levert, R. Kovacevic, Feasibility study of laser welding assisted by filler wire for narrow-gap butt-jointed plates of high-strength steel, Weld. World., 57 (2013), 693-699, doi:10.1007/s40194-013-0068-9

${ }^{5}$ Z. Qian, S. Chumbley, E. Johnson, The effect of specimen dimension on residual stress relaxation of carburized and quenched steels, Mater. Sci. Eng. A., 529 (2011), 246-252, doi:10.1016/j.msea.2011. 09.024

${ }^{6}$ X. Wang, X. Gong, K. Chou, Scanning speed effect on mechanical properties of Ti-6Al-4V alloy processed by electron beam additive 
manufacturing, Procedia Manuf., 1 (2015), 287-295, doi:10.1016/ j.promfg.2015.09.026

E. Sallica-Leva, A. L. Jardini, J. B. Fogagnolo, Microstructure and mechanical behavior of porous Ti-6Al-4V parts obtained by selective laser melting, J. Mech. Behav. Biomed. Mater., 26 (2013), 98-108, doi:10.1016/j.jmbbm.2013.05.011

${ }^{8}$ X. Wang, X. Gong, K. Chou, Review on powder-bed laser additive manufacturing of Inconel 718 parts, Proc. Inst. Mech. Eng. Part B J. Eng. Manuf., (2015), 1-14, doi:10.1115/MSEC2015-9322

${ }^{9} \mathrm{X}$. Wang, K. Chou, Electron backscatter diffraction analysis of Inconel 718 parts fabricated by selective laser melting additive manufacturing, JOM., 69 (2017), 402-408, doi:10.1007/s11837-0162198-1

${ }^{10}$ Y. Chen, Z. Xu, C. Smith, J. Sankar, Recent advances on the development of magnesium alloys for biodegradable implants, Acta Biomater., 10 (2014), 4561-4573, doi:10.1016/j.actbio.2014.07.005

${ }^{11} \mathrm{~F}$. Czerwinski, Controlling the ignition and flammability of magnesium for aerospace applications, Corros. Sci., 86 (2014), 1-16, doi:10.1016/j.corsci.2014.04.047

${ }^{12}$ P. Saha, M. K. Datta, O. I. Velikokhatnyi, A. Manivannan, D. Alman, P. N. Kumta, Rechargeable magnesium battery: Current status and key challenges for the future, Prog. Mater. Sci., 46 (2015), 1-86, doi:10.1016/j.pmatsci.2014.04.001

${ }^{13}$ A. Atrens, G.L. Song, F. Cao, Z. Shi, P. K. Bowen, Advances in Mg corrosion and research suggestions, J. Magnes. Alloy., 1 (2013), 177-200, doi:10.1016/j.jma.2013.09.003

${ }^{14}$ H. Matsubara, Y. Ichige, K. Fujita, H. Nishiyama, K. Hodouchi, Effect of impurity $\mathrm{Fe}$ on corrosion behavior of AM50 and AM60 magnesium alloys, Corros. Sci., 66 (2013), 203-210, doi:10.1016/ j.corsci.2012.09.021

${ }^{15}$ X. Wang, T. Keya, K. Chou, Build height effect on the Inconel 718 parts fabricated by selective laser melting, Procedia Manuf., 5 (2016), 1006-1017, doi:10.1016/j.promfg.2016.08.089

${ }^{16} \mathrm{H}$. Mirzadeh, Constitutive analysis of $\mathrm{Mg}-\mathrm{Al}-\mathrm{Zn}$ magnesium alloys during hot deformation, Mech. Mater., 77 (2014), 80-85, doi:10.1016/j.mechmat.2014.07.004

${ }^{17}$ J. LI, J. XIE, J. JIN, Z. WANG, Microstructural evolution of AZ91 magnesium alloy during extrusion and heat treatment, Trans. Nonferrous Met. Soc. China, 22 (2012), 1028-1034. doi:10.1016/ S1003-6326(11)61279-X

${ }^{18}$ N. D. Nam, Corrosion behavior of $\mathrm{Mg}-5 \mathrm{Al}$ based magnesium alloy with 1 w/\% $\mathrm{Sn}, \mathrm{Mn}$ and $\mathrm{Zn}$ additions in 3.5 w/\% NaCl solution, J. Magnes. Alloy., 2 (2014), 190-195, doi:10.1016/j.jma.2014.06.002

${ }^{19}$ M. Yang, Y. Liu, J. Liu, Y. Song, Corrosion and mechanical properties of AM50 magnesium alloy after being modified by $1 \mathrm{w} / \%$ rare earth element gadolinium, J. Rare Earths, 32 (2014), 558-563, doi:10.1016/S1002-0721(14)60108-3

${ }^{20}$ W. Liu, F. Cao, L. Chang, Z. Zhang, J. Zhang, Effect of rare earth element $\mathrm{Ce}$ and La on corrosion behavior of AM60 magnesium alloy, Corros. Sci., 51 (2009), 1334-1343, doi:10.1016/j.corsci.2009. 03.018

${ }^{21}$ A. Kielbus, G. Moskal, R. Cibis, Microstructure and corrosion resistance of magnesium alloys with galvanic coatings, Procedia Eng., 10 (2011), 1841-1846, doi:10.1016/j.proeng.2011.04.306

${ }^{22}$ C. Wu, J. Zhang, State-of-art on corrosion and protection of magnesium alloys based on patent literatures, Trans. Nonferrous Met. Soc. China, 21 (2011), 892-902, doi:10.1016/S1003-6326(11) 60799-1
${ }^{23}$ M. Carboneras, L. S. Hernández, J. A. del Valle, M. C. GarcíaAlonso, M. L. Escudero, Corrosion protection of different environmentally friendly coatings on powder metallurgy magnesium, J. Alloys Compd., 496 (2010), 442-448, doi:10.1016/j.jallcom.2010. 02.043

${ }^{24}$ W. Liu, J. Ma, M. M. Atabaki, R. Kovacevic, Joining of advanced high-strength steel to AA 6061 alloy by using Fe/Al structural transition joint, Mater. Des., 68 (2015), 146-157, doi:10.1016/j.matdes.2014.12.028

${ }^{25}$ D. Orlov, G. Raab, T. T. Lamark, M. Popov, Y. Estrin, Improvement of mechanical properties of magnesium alloy ZK60 by integrated extrusion and equal channel angular pressing, Acta Mater., 59 (2011), 375-385, doi:10.1016/j.actamat.2010.09.043

${ }^{26}$ H. Hu, Y. Ying, Z. Qu, X. Wang, Influences of extrusion temperatures on the wear behavior of magnesium alloy AZ31 fabricated by the extrusion shear process, Wear Test., 59 (2017), 41-46, doi:10.3139/120.110962

${ }^{27}$ R. B. Figueiredo, P. R. Cetlin, T. G. Langdon, The processing of difficult-to-work alloys by ECAP with an emphasis on magnesium alloys, Acta Mater., 55 (2007) 14, 4769-4779, doi:10.1016/ j.actamat.2007.04.043

${ }^{28}$ K. Matsubara, Y. Miyahara, Z. Horita, T. G. Langdon, Developing superplasticity in a magnesium alloy through a combination of extrusion and ECAP, Acta Mater., 51 (2003), 3073-3084, doi:10.1016/S1359-6454(03)00118-6

${ }^{29}$ Y. Z. Du, X. G. Qiao, M. Y. Zheng, K. Wu, S. W. Xu, The microstructure, texture and mechanical properties of extruded $\mathrm{Mg}-5.3 \mathrm{Zn}-0.2 \mathrm{Ca}-0.5 \mathrm{Ce}(\mathrm{wt} \%)$ alloy, Mater. Sci. Eng. A, 620 (2015), 164-171, doi:10.1016/j.msea.2014.10.028

${ }^{30}$ H. J. Hu, Z. Sun, Z. W. OU, X. Q. Wang, Wear behaviors and wear mechanisms of wrought magnesium alloy AZ31 fabricated by extrusion-shear, Eng. Fail. Anal., 72 (2017), 25-33, doi:10.1016/ j.engfailanal.2016.11.014

${ }^{31}$ H. J. Hu, Y. Y. Li, X. Wang, D. F. Zhang, M. B. Yang, Effects of extrusion-shear process conditions on the microstructures and mechanical properties of AZ31 magnesium alloy, High Temp. Mater. Process., 35 (2016), 967-972, doi:10.1515/htmp-2015-0090

${ }^{32}$ D. Orlov, K. D. Ralston, N. Birbilis, Y. Estrin, Enhanced corrosion resistance of Mg alloy ZK60 after processing by integrated extrusion and equal channel angular pressing, Acta Mater., 59 (2011), 6176-6186, doi:10.1016/j.actamat.2011.06.033

${ }^{33}$ W. Song, H. J. Martin, A. Hicks, D.Seely, C. A. Walton, W. B. Lawrimore II, P. T. Wang, M. F. Horstemeyer, Corrosion behaviour of extruded AM30 magnesium alloy under salt-spray and immersion environments, Corros. Sci., 78 (2014), 353-368, doi:10.1016/ j.corsci.2013.10.020

${ }^{34}$ Q. Chen, B. Yuan, J. Lin, X. Xia, Z. Zhao, D. Shu, Comparisons of microstructure, thixoformability and mechanical properties of high performance wrought magnesium alloys reheated from the as-cast and extruded states, J. Alloys Compd., 584 (2014), 63-75, doi:10.1016/j.jallcom.2013.08.218

${ }^{35}$ X. Xia, Q. Chen, Z. Zhao, M. Ma, X. Li, K. Zhang, Microstructure, texture and mechanical properties of coarse-grained $\mathrm{Mg}-\mathrm{Gd}-\mathrm{Y}-\mathrm{Nd}-\mathrm{Zr}$ alloy processed by multidirectional forging, $\mathrm{J}$. Alloys Compd., 623 (2015), 62-68, doi:10.1016/j.jallcom.2014. 10.084 